\title{
KEARIFAN LOKAL DALAM PENGELOLAAN SUMBERDAYA PERIKANAN
}

\author{
Nanang Widarmanto \\ Balai Riset Pemulihan dan Konservasi Sumberdaya Ikan \\ J1. Cilalawi No. 1. Jatiluhur Purwakarta \\ Email:widarmanto.n80@gmail.com
}

\begin{abstract}
Indonesia has large potential fishery resources, both marine fisheries and inland public waters. The potential of existing fishing is expected to have an impact on the people's beneficiaries. However its resources are open access and common property without the accompaniment surveillance which tends to encourage people at maximum utilization patterns and unsustainable. One approach to resource management effort, which is quite effective is the power of local construction. This paper aims to find out the various models of local construction in the management of fishery resources, especially in public waters. The writing method uses the desk or literature study. The study shows that the implementation of community-based management model is proven to deliver results quite effective and efficient. Management efficiency, which reduces conflict of fishermen and the sustainability of the resource is obtained from the management model based on local wisdom, which puts public participation as a key indicator in the implementation of resource management.
\end{abstract}

Key words: Local wisdom, resources, fishery management.

\section{Pendahuluan}

Pengelolaan perairan Indonesia dan negara-negara berkembang lainnya, baik perairan darat atau tawar, maupun perairan laut dan pesisir mengalami kendala-kendala dan sangat erat kaitannya dengan pemenuhan kebutuhan masyarakat sekitar, sehingga dengan alasan kebutuhan ekonomi dan kemiskinan serta sangat sedikitnya lapangan pekerjaan, menyebabkan masyarakat sekitar pantai mencari penghasilan dari alam sekitar dan merupakan tempat pemenuhan kebutuhan ekonomi yang sangat mudah; ditambah kurangnya pengawasan dan pembinaan, laju kerusakan alam semakin besar dan semakin meningkat.

Banyak masyarakat melakukan praktek ilegal di dalam memanfaatkan sumberdaya yang ada, seperti penangkapan ikan dengan menggunakan bom, potasium dan penangkapan yang tak terkendali termasuk nutfah yang ada di wilayah tersebut dan tanpa memikirkan keberlanjutannya. Berbagai tata aturan dalam pemanfaatan sumberdaya, sebenarnya telah dilakukan, baik melalui undang- undang maupun peraturan di tingkat desa; namun sifatnya yang terbuka (open access) dan menjadi milik umum (common property), didukung dengan tuntutan kebutuhan yang cenderung terus meningkat, mendorong beberapa pihak untuk berperilaku kurang arif dalam memanfaatkannya.

Berdasarkan kondisi tersebut bahwa telah banyak sumberdaya perairan yang rusak terutama di daerah perairan darat atau tawar, maka perlu ada upaya yang dilakukan untuk mencegah meluasnya kegiatan pengrusakan sumberdaya perairan tersebut. Adapun upaya-upaya yang harus dilakukan adalah dengan cara memadukan keinginan yang ada dalam masyarakat sekitar dengan tujuan-tujuan yang akan dicapai oleh pemerintah dalam rangka menjaga dan menyelamatkan sumberdaya perairan dari kerusakan.

Salah satu upaya yang dapat dilakukan adalah dengan mencari dan memfungsikan kembali adat kebiasaan masyarakat setempat di dalam mengelola sumberdaya mereka yang secara turun-temurun telah ada dan efektif dilakukan pada wilayah tersebut yang biasa disebut dengan kearifan lokal, ikut 
berperan dalam pengelolaan sumberdaya alam dan lingkungannya. Namun demikian kearifan lokal juga tidak lepas dari berbagai tantangan seperti bertambahnya terus jumlah penduduk, teknologi modern dan budaya, modal besar serta kemiskinan dan kesenjangan. Adapun prospek kearifan lokal di masa depan sangat dipengaruhi oleh pengetahuan masyarakat, inovasi teknologi, permintaan pasar, pemanfaatan dan pelestarian keanekaragaman hayati di lingkungannya serta berbagai kebijakan pemerintah yang berkaitan langsung dengan pengelolaan sumberdaya alam dan lingkungan serta peran masyarakat lokal (Suhartini, 2009).

Menurut Francis Wahono (2005), kearifan lokal tidak hanya berhenti pada etika, tetapi sampai pada norma dan tindakan dan tingkah laku, sehingga kearifan lokal dapat menjadi seperti religi yang memedomani manusia dalam bersikap dan bertindak, baik dalam konteks kehidupan sehari-hari maupun menentukan peradaban manusia yang lebih jauh. Kearifan Lokal merupakan solusi dalam menjaga kelestarian perairan, beberapa peraturan adat seringkali lebih dipatuhi dibanding peraturan pemerintah, karena kalau melanggar adat, maka bisa dikucilkan oleh masyarakat. Peraturan adat biasanya mengatur kapan warga boleh mencari ikan, cara-cara yang sesuai, serta aturan lain yang bertujuan untuk kelestarian ikan dan hasil-hasil perairan, sehingga dapat dipertahankan sampai anak cucunya kelak.

Sejauh mana peran kearifan lokal tersebut dalam mewujudkan sumberdaya ikan yang lestari, kita harus mengenal pemahaman tersebut, serta berbagai praktek keberhasilannya. Artikel ini bertujuan untuk mengetahui berbagai model konstruksi lokal dalam pengelolaan sumberdaya perikanan khususnya di perairan umum.

\section{Pengertian Kearifan Lokal}

Dalam sejumlah kepustakaan, kearifan lokal sering diidentikkan dengan local wisdom, atau yang lebih tepat local knowledge. Kearifan lokal idealnya lebih pas disebut penemuan tradisi (invention of tradition). Terence Ranger \& Eric Hobsbawm (1983) mengemukakan "invented tradition" sebagai seperangkat praktik, yang biasanya ditentukan oleh aturan-aturan yang diterima secara jelas atau samar-samar maupun suatu ritual atau sifat simbolik, yang ingin menanamkan nilai-nilai dan norma-norma perilaku tertentu melalui pengulangan, yang secara otomatis mengimplikasikan adanya kesinambungan dengan masa lalu. Pengertian tersebut mengandung arti bahwa kearifan lokal memiliki ciri bermatra tiga waktu (masa lalu, sekarang, dan yang akan datang), sehingga dimungkinkan ada upaya sambung-menyambung dan seiring kehidupan manusia dalam setting dan konteks yang berubah-ubah sesuai zamannya. Di sini yang dipentingkan adalah bagaimana kearifan lokal dapat memberikan kebermafaatan yang berkelanjutan bagi masyarakat seluas-luasnya yang menjadi pendukung kebudayaan setempat.

Kearifan local atau tradisional sesungguhnya merupakan bagian dari etika dan morolitas yang membantu manusia untuk menjawab pertanyaan moral apa yang harus dilakukan, bagaimana harus bertindak khususnya di bidang pengelolaan lingkungan dan sumberdaya alam. Hal tersebut menyiratkan bahwa kearifan lokal memainkan peran dalam mengembangkan perilaku, baik secara individu maupun secara kelompok dalam kaitan dengan lingkungan dan upaya pengelolaan sumberdaya alam. Selain itu, kearifan local membantu kita untuk mengembangkan sistem sosial politik yang ramah terhadap lingkungan serta mengambil keputusan dan kebijakan yang berdampak terhadap lingkungan atau sumberdaya alam termasuk sumberdaya alam pesisir dan laut. Etika yang berarti adat istiadat atau kebiasaan, dalam arti kebiasaan hidup yang baik, tata cara hidup yang baik, baik pada diri seseorang atau pada kelompok masyarakat. Kebiasaan hidup yang baik ini dianut dan diwariskan dari satu generasi ke generasi yang lain (Keraf, 2002). Kebiasaan hidup yang baik ini kemudian dibakukan dalam bentuk kaidah, aturan, norma yang 
disebarluaskan, dikenal, dipahami dan diajarkan dalam masyarakat. Oleh karena itu etika dipahami sebagai ajaran yang berisikan aturan tentang bagaimana manusia harus hidup baik sebagai manusia dan juga etika dipahami sebagai ajaran yang berisikan perintah dan larangan tentang baik-buruknya perilaku manusia yaitu perintah yang harus dipatuhi dan larangan yang harus dihindari. Pengertian keraifan lokal (tradisional) menurut Keraf (2002) adalah semua bentuk pengetahuan, keyakinan, pemahaman atau wawasan serta adat kebiasaan atau etika yang menuntun perilaku manusia dalam kehidupan di dalam komunitas ekologis. Dijelaskan pula bahwa kearifan local atau tradisional bukan hanya menyangkut pengetahuan dan pemahaman masyarakat tentang manusia dan bagaimana relasi yang baik di antara manusia, melainkan juga menyangkut pengetahuan, pemahaman dan adat kebiasaan tentang manusia, alam dan bagaimana relasi di antara penghuni komunitas ekologis ini harus dibangun.

Beberapa pengertian di atas, kemudian dirumuskan ke arah yang lebih konkrit pada beberapa model pelaksanaan kearifan lokal pada masing-masing daerah dan budaya bahkan lengkap dengan pranata hukumnya. Adrianto (2005) mengemukakan beberapa bentuk kearifan lokal, seperti di Jambi misalnya, lubuk larangan (river protected area) dirumuskan sebagai sebuah lubuk di sungai-sungai yang dibiarkan selama 6 bulan hingga 2 tahun tidak dipanen ikannya, sehingga ikan punya cukup waktu untuk berkembang biak. Penutupan sebuah lubuk dilakukan dengan membacakan surah Yasin 40 kali. Bagi siapa yang mengambil ikan selama penutupan lubuk akan dikenai sanksi adat. Setelah dibuka, ikan dipanen dengan cara dilelang. Hasilnya digunakan untuk kepentingan kelompok. Di Maluku, kearifan lokal atau lebih dikenal dengan istilah Sasi dapat diartikan sebagai larangan untuk mengambil hasil sumberdaya alam tertentu sebagai upaya pelestarian demi menjaga mutu dan populasi sumberdaya hayati (hewani maupun nabati) alam tersebut. Karena peraturan-peraturan dalam pelaksanaan larangan ini juga menyangkut pengaturan hubungan manusia dengan alam dan antar manusia dalam wilayah yang dikenakan larangan tersebut, maka sasi, pada hakekatnya, juga merupakan suatu upaya untuk memelihara tata-krama hidup bermasyarakat, termasuk upaya ke arah pemerataan pembagian atau pendapatan dari hasil sumberdaya alam sekitar kepada seluruh warga setempat. Di negeri Haruku, dikenal empat jenis sasi, yaitu 1) Sasi Laut; 2) Sasi Kali; 3) Sasi Hutan; 4) Sasi dalam Negeri.

\section{1. Perkembangan Kearifan Lokal Pengelolaan Sumberdaya Perikanan di Indonesia}

Pengelolaan sumberdaya alam dan lingkungan yang berbasis kearifan lokal dapat ditemui di sebagian besar wilayah dii Indonesia. Upaya pengelolaan berbasis kearifan lokal berlaku mulai dari pengelolaan sumberdaya air, hutan, ikan baik di perairan darat maupun pesisir laut, bahkan dalam sistem usaha. Kearifan lokal dalam pelestarian sumberdaya alam sudah ada di masing-masing daerah, misalnya Sasi di Saparua; lahan Lebak di Kalimantan Timur; Pengelolaan Perairan Pesisir Desa Tanjung Barari di Biak; Sistem Rumpon Way Muli di Lampung; Manajemen Danau Sentarum di Kalimantan Barat; Pengelolaan Terumbu Karang di Jemluk Bali; Panglima Laot dan pengelolaan Rawa Singkil di Nangroe Aceh Darussalam; Lubuk Larangan di Jambi; lubuk larangan, penataan ruang banua/huta, tempat keramat 'naborgo-borgo' atau 'harangan rarangan' (hutan larangan) di Mandailing Sumatera Utara; dan lain-lainnya. Hal-hal tersebut adalah pola-pola pelestarian oleh lembagalembaga adat dan masyarakat setempat.

Terdapat pula bentuk kearifan lokal dalam pengelolaan sumberdaya alam, yakni kearifan lokal pada masyarakat Kuala Singkil, Aceh, tidak jauh berbeda dengan apa yang sudah pernah terjadi di beberapa tempat; misalnya, bisa dilihat pada tumbuhan bakong dibiarkan hidup bebas, karena mereka meyakini, jika tumbuhan bakong itu hilang, maka kampung mereka akan tergenang air dari sungai Singkil dan 
beberapa anak sungai lainnya. Bahkan jika mereka akan mengambil madu di dalam hutan, acap kali harus dikawal oleh Panglima Uten (orang dari pemukiman yang bertanggung jawab atas Sungai dan Hutan), melakukan ritual yang diyakini agar lebahlebah tersebut tidak hilang atau berubah jadi jahat. Jika hal itu dilanggar, maka warga akan dikenakan sangsi dengan bekerja (gotong royong) di Masjid selama 3 hari. Sedangkan kearifan berupa lubuk larangan, awig-awig dan sasi di Maluku merupakan beberapa bentuk kearifan dalam pengelolaan sumberdaya perikanan.

\section{2. Bentuk-bentuk Kearifan Lokal dalam Pengelolaan Sumberdaya Perikanan Perairan Umum}

\section{2. 1. Lubuk Larangan di Jambi}

Dalam upaya pengelolaan sumberdaya ikan, pemerintah kota Jambi telah mengembangkan kawasan perlindungan berbasis kearifan lokal, yakni Suaka Mina dan Lubuk Larangan. Perbedaannnya, jika Suaka Mina merupakan satu kawasan yang sama sekali ikannya tidak boleh ditangkap, ikan di Lubuk Larangan boleh dipanen namun diatur sesuai adat setempat. Hukum adat setempat sekaligus merupakan manifestasi dari kearifan lokal berisi aturan yaitu dengan membiarkan sebuah lubuk sungai selama 6 bulan hingga 2 tahun tidak dipanen, ikan punya cukup waktu untuk berkembang biak. Penutupan sebuah lubuk dilakukan dengan membacakan surah Yasin 40 kali. Bagi siapa yang mengambil ikan selama penutupan lubuk akan dikenai sanksi adat. Setelah dibuka, ikan dipanen dengan cara dilelang. Hasilnya digunakan untuk kepentingan kelompok. Pada saat ini, pemerintah propinsi Jambi telah menetapkan 6 kawasan suaka perikanan perairan tawar, dan 35 buah lubuk larangan. Beberapa di antaranya adalah lubuk larangan Danau Arang-Arang dan Danau Mahligai di Kabupaten Muara Jambi.

Danau Arang-Arang tepatnya terletak di Desa Arang-Arang, di mana terdapat minimal 4 (empat) anggota masyarakat nelayan yang dipercaya Ketua
Danau untuk mengawasi penangkapan ikan. Jika ada kejadian tentang pencurian ikan di suaka perikanan atau seseorang mencuri ikan milik nelayan lainnya maka orang yang dipercaya tersebut melapor kepada Ketua Danau untuk selanjutnya ditindaklanjuti. Hal ini sesuai dengan hasil penelitian bahwa sistem pengawasan suaka perikanan yang diterapkan di desa Arang-Arang adalah sistem pengawasan yang dilaksanakan oleh masyarakat secara bersama. Kemudian dalam pelaksanaannya di lapangan dibantu oleh 15 orang yang dipercaya oleh Ketua Keamanan dan Ketua Danau yang berfungsi sebagai pengawas lapangan yang utama untuk pengamanan suaka perikanan. Danau ini telah diatur berdasarkan SK Bupati Muara Jambi Nomor 271 Tahun 2003. Tidak jauh berbeda dengan dengan Danau Arang-Arang, Danau Mahligai telah diatur berdasarkan SK Bupati daerah TK. II Batanghari Nomor 362 Tahun 1996.

\section{2. 2. Lubuk Larangan di Sumatera Utara}

Di Sumatera Utara lubuk larangan merupakan bentangan sungai yang jernih penuh dengan ikan, sangat menggoda untuk diambil baik secara memancing, menjala atau menembak. Sungguh sangat luar biasa ikan yang jumlahnya begitu banyak dan kelihatan dengan jelas, tidak ada yang berani mengambilnya, baik secara terang-terangan maupun secara sembunyi-sembunyi. Kearifan lokal berupa lubuk larangan telah berkembang hampir di seluruh wilayah yang bertopografi paparan sungai-sungai, meliputi wilayah Kabupaten Mandailing dan Padang Sidempuan. Di Sungai Batang Gadis (Mandailin), mulai dari hulu di kawasan Pekantan, Kecamatan Muara Sipongi hingga ke hilir di Kecamatan Kotanopan hingga ke Penyabungan banyak didapati lubuk larangan, demikiam juga di Sungai Batang Natal. Pranata hukum yang secara sosial dikembangkan dalam masyarakat adalah sebagai berikut.

(1) Penetapan daerah lubuk larangan di mana masyarakat melepaskan ikan dan kemudian diambil pada waktu tertentu - 
biasanya 6-12 bulan - secara bersamaan.

(2) Hasilnya akan digunakan untuk berbagai keperluan desa. Tapi bila ada yang mengambil ikan di luar jadwal yang telah ditentukan, maka ia akan dikenai sanksi desa ataupun kampung.

Sedangkan pranata hukum pada lubuk larangan yang terdapat di pedalaman Padang Sidimpuan tepatnya di Desa Pardomuan diwujudkan dalam bentuk kepatuhan masyarakat untuk tidak mengeksploitasi ikan sebelum ada pengumuman lubuk larangan dinyatakan dibuka secara umum. Ada beberapa kemungkinan mengapa masyarakat tidak berani mengambil ikan sebelum event lubuk larangan dibuka, sebagai berikut.

1. Takut kena denda sebanyak Rp. 1.000.000,-
2. Takut kena tuah pawang lubuk larangan.

3. Kesadaran masayarakat yang sudah tumbuh.

Jarak dan ruang waktu diatur secara sederhana oleh pemangku adat. Lubuk larangan dibuka tiap 1 tahun sekali dan berjarak $3 \mathrm{~km}$, dengan demikian siklus perkembangbiakan ikan dapat berjalan secara alamiah dan lestari. Adapun cara penangkapan ikan di saat acara pembukaan lubuk larangan hanya diperbolehkan dengan cara memancing, menembak, menombak dan menjaring. Penggunaan obat atau racun sangat dilarang dan dikenakan sanksi adat. Sampel lokasi lubuk larangan dapat dilihat pada Gambar 1 dan kegiatan panen raya pada Gambar 2, sebagai berikut.

\section{Gambar 1. Dua Lokasi Lubuk Larangan di Sepanjang Sungai Batang Gadis}
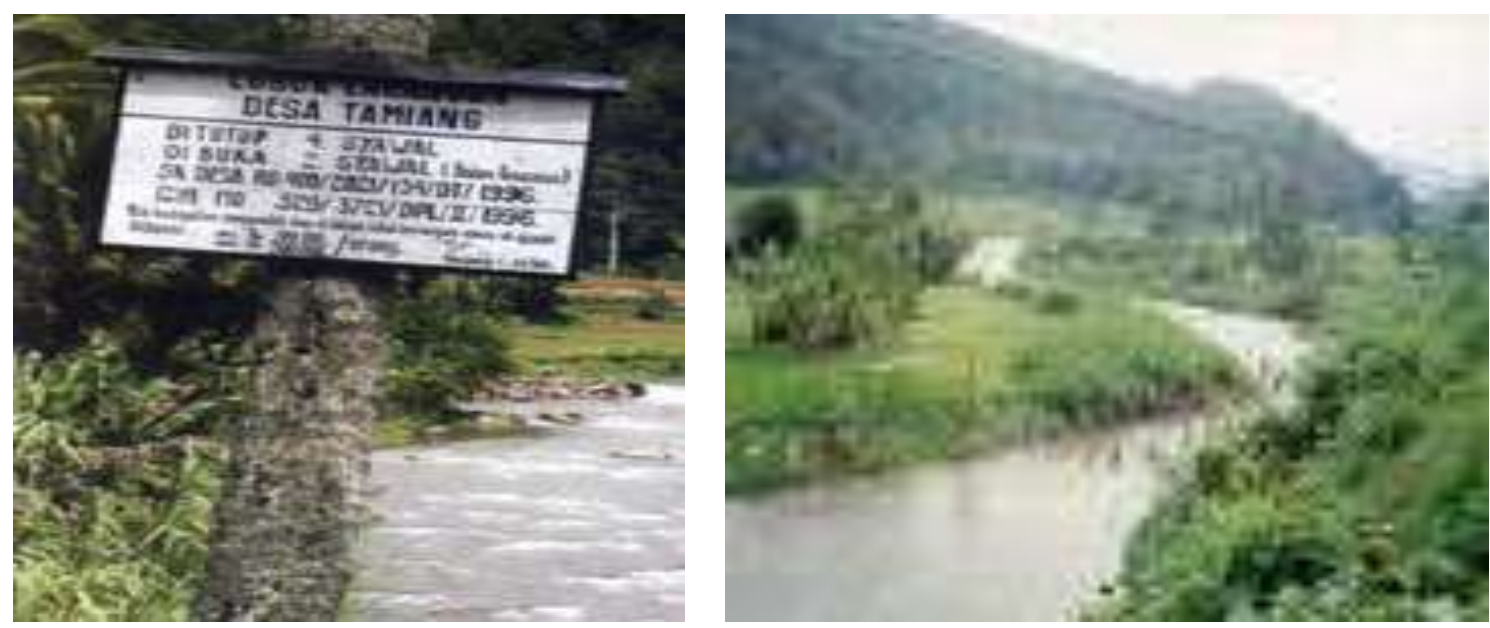

Gambar 2. Kegiatan Panen Raya di Perairan Lubuk Larangan
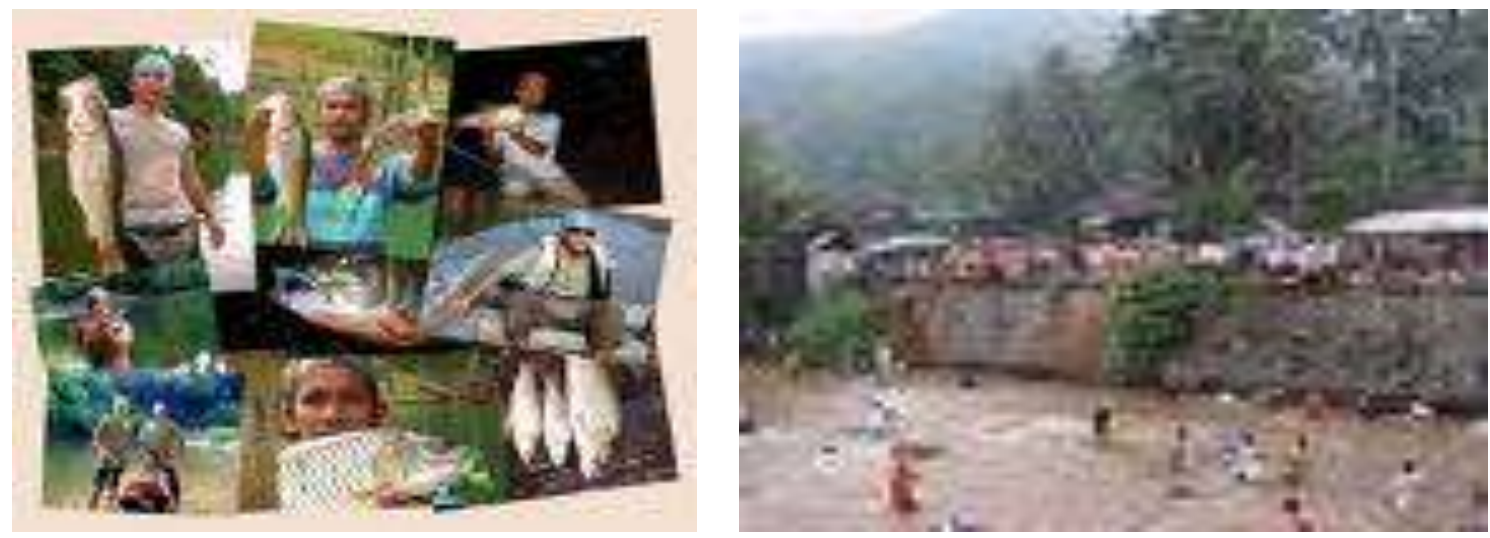


\section{3. Bentuk-Bentuk Kearifan Lokal dalam Pengelolaan Sumberdaya Perikanan Pesisir dan Laut}

\section{3. 1. Awig-Awig di Bali}

Di Bali, awig-awig merupakan aturanaturan yang dibuat oleh Krama Desa melalui Paruman Desa adat dan umumnya banyak yang tidak disuratkan. Aturan-aturan tersebut mengatur keseluruhan tatanan sosial kemasyarakatan termasuk dalam kaitannya dalam pengelolaan sumberdaya perairan. Dalam perkembangannya, dewasa ini telah berhasil disuratkan awig-awig tersebut sebagai pedoman bagi pengurus desa adat dalam melaksanakan kewajibannya maupun bagi warga, dan di dalam awig-awig tersebut kita jumpai sanksi-sanksi bagi warga desa yang melanggarnya. Di dalam awig-awig desa ini dapat dilihat perbuatan atau tindakan yang dilarang serta sanksisanksinya, baik sanksi yang dijatuhkan kepada warga atau keluarganya atau dibebankan kepada masyarakat desa sendiri (Wyadnyana, 1995).

\section{3. 2. Awig-awig di Nusa Tenggara}

Selanjutnya di Nusa Tenggara, awigawig merupakan produk hukum masyarakat adat Pulau Lombok, yang berisi peraturan tertulis maupun tidak tertulis yang bertujuan mengatur tata tertib kehidupan komunitas yang terikat dalam satu wilayah domisili (desa adat atau krama desa). Di dalam awigawig termuat peraturan kehidupan yang harmonis antara anggota komunitas dalam kehidupan sehari-hari, baik dalam kehidupan beragama maupun dalam hubungan masyarakat lainnya, menyangkut hak, kewajiban, dan sanksi atas pelanggaran (peringatan, denda, perampasan, dan pengusiran) termasuk sanksi spiritual.

Awig-awig merupakan bentuk kepedulian dan partisipasi masyarakat dalam pengelolaan sumberdaya perikanan. Di kawasan Teluk Ekas, misalnya telah tersusun 4 bentuk awig-awig yang berkaitan dengan pengelolaan lingkungan, sebagai berikut.
(1) Awig-awig tentang sumberdaya perikanan;

(2) awig-awig tentang pengelolaan suaka perikanan (fish sanctuary);

(3) awig-awig tentang pengelolaan sea ranching spat mutiara; dan

(4) awig-awig krama/garap di tingkat dusun, yang mengatur tentang keamanan dusun dan sanksi terhadap pelanggar keamanan dusun khususnya di dusun Batunampar.

Di dalam awig-awig pengelolaan sumberdaya perikanan diatur mengenai berbagai hal, yaitu (a) ketentuan mengenai penetapan zona penangkapan; (b) wilayah, alat tangkap dan jenis ikan yang boleh ditangkap; (c) pengaturan budidaya laut; (d) larangan penangkapan ikan dengan bom, bahan berbahaya dan beracun; (e) perlindungan hutan bakau, pasir pantai, batu karang dan biota lainnya; (f) kelembagaan dan sumberdana pengelolaan; dan (g) sanksi dan prosedur pemberian sanksi.

Awig-awig tentang pengelolaan suaka perikanan (fish sanctuary) mengatur secara khusus tentang suaka perikanan yang terletak di kawasan terumbu karang Sapak Kokok, Teluk Ekas. Dalam ketentuan umum pasal 1 dinyatakan bahwa yang dimaksud dengan suaka perikanan adalah kawasan laut yang dilindungi secara permanen dari segala kegiatan eksploitasi. Awig-awig ini mengatur tentang (a) cakupan wilayah suaka perikanan; (b) hak dan kewajiban masyarakat; (c) kegiatan yang diperbolehkan dan dilarang, kelembagaan pengelolaan dan (d) sanksi dan prosedur pemberian sanksi.

Awig-awig pengelolaan sea ranching spat mutiara mengatur ketentuan-ketentuan mengenai (a) cakupan wilayah/lokasi sea ranching; (b) pengelolaan; (c) pemanfaatan hasil; (d) kegiatan yang dilarang; dan (e) sanksi dan prosedur pemberian sanksi. Selanjutnya awig-awig tentang krama/garap, berisi ketentuan pemberian sanksi terhadap para pelanggar tata krama atau keamanan khususnya pencurian, yang khusus berlaku pada masyarakat di dusun Batunampar. Dalam awig-awig ini ditentukan bahwa setiap terjadi pencurian harus diselesaikan melalui krama/garap. 
Pada hari pelaksanaan krama/garap, seluruh warga berkumpul di suatu tempat di luar dusun dan mengharuskan setiap warga untuk meminum "air suci." Warga yang tidak hadir tanpa alasan yang benar dapat dicurigai sebagai pencuri atau dikenakan sanksi membayar denda bahkan senilai barang yang hilang.

Dalam praktiknya, kearifan lokal awig awig terbukti mampu meminimalkan berbagai konflik yang sebelumnya sering terjadi, yaitu pertama, hilangnya konflik internal antar masyarakat nelayan lokal yang disebabkan oleh pelanggaran zona tangkapan; dan kedua, berkurangnya konflik antara nelayan lokal dan nelayan luar yang menggunakan alat tangkap yang sifatnya merusak seperti dinamit, potasium sianida dan bahan-bahan beracun lainnya. Sejak disahkannya aturan lokal awig-awig pada tanggal 19 Maret 2000 hingga Juli 2002, hanya terjadi pelanggaran (pengeboman dan pemotasan) sebanyak tujuh kali yang umumnya dilakukan oleh masyarakat nelayan di luar Lombok Barat, seperti Lombok Timur, Jawa Timur, dan Bali.

Penguatan hak ulayat laut di Indonesia harus menjadi perhatian utama dalam membuat rancangan kebijakan yang akan ditetapkan. Hal ini seperti yang dilakukan oleh masyarakat Lombok Utara dalam melakukan pengelolaan Sumber Daya Kelautan dan Perikanan/SDKP. Adapun proses penguatan nilai-nilai lokal (hak ulayat laut/HUL) menjadi model pengelolaan SDKP kolaboratif (CoManagement) yang dikenal awig-awig yang merupakan rekonstruksi dari adat-istiadat atau kebudayaan yang berakar dari masyarakat lokal yaitu upacara adat sawen. Setelah rekonstruksi upacara adat sawen, maka tahapan revitalisasi terhadap aturan yang disepakati bersama dengan cara memberikan pengakuan, pemberian peran, penguatan dan formalisasi oleh kedua unsur, yaitu (1) masyarakat, yang diwakili oleh LSM, tokoh masyarakat, nelayan dan satuan petugas lingkungan (Satgas); dan (2) pemerintah yang diwakili oleh kepala desa, kecamatan, Balai Konservasi Sumberdaya Alam, Kepolisian, dan TNI.
Dengan demikian, kegiatan perikanan yang bertanggungjawab (responsible fisheries) dapat diwujudkan dengan cara melakukan rekonstruksi dan revitalisasi kearifan-kearifan lokal atau Hak Ulayat Laut yang dikenal dengan model Community Based Management/CBM menjadi model Co-Management yang lebih kompleks dan dengan menggabungkan model kebijakan yang dijalankan oleh pemerintah (Centralized Government

Management/CGM).

\section{4. Peran Kearifan Lokal dalam Pengelolaan Sumberdaya Perikanan}

Pada beberapa kasus, kearifan lokal, tidak saja terbukti mampu menyelamatkan sumberdaya, namun juga mampu mengubah perilaku masyarakat terhadap sumberdaya tersebut. Sebagai contoh adalah implementasi kearifan lokal dalam bentuk lubuk larangan. Dari sudut pandang perspektif teoritis paling tidak ada dua hal istimewa dari fenomena pengelolaan sungai dengan sistem lubuk larangan tersebut, yakni sebagai berikut.

\section{4. 1. Kemampuan komunitas setempat} untuk melakukan perubahan radikal dalam konsepsi penguasaan sumber daya alam (sungai), dari yang semula dipahami sebagai sumber daya yang bisa diakses secara bebas oleh siapa pun (open access) menjadi sumber daya yang dimiliki secara komunal (communally owned resources).

Dengan perubahan konsepsi tersebut, maka kecenderungan eksploitasi berlebihan terhadap sumber daya alam terkurangi, sehingga gejala "tragedi milik bersama" (tragedy of the common) dalam pengelolaan sumber daya yang bersifat akses terbuka tidak terjadi, terutama dalam konteks pengelolaan sumber daya yang ada di sungai.

\section{4. 2. Konsistensi dalam menegakkan "rule-in-uses" yang telah ditetapkan}

Implementasi kearifan lokal terbukti mampu menggiring masyarakat pada suatu sikap yang konsisten, yakni konsistensi 
dalam penegakan aturan main yang tidak pandang bulu, serta pada kemauan mereka bersikap transparan dalam semua tahapan pengelolaan. Keterbukaan atau transparansi dalam pengelolaan keuangan, terutama dalam pengelolaan keuangan yang dihimpun dari hasil lubuk larangan, menjadi pijakan kuat bagi terbangunnya sikap saling percaya di antara warga komunitas. Sikap saling percaya itu menjadi semacam perekat untuk menyatukan sesuatu yang ideasional (institusi pengelolaan) dengan yang faktual (partisipasi warga komunitas) dalam konteks pengelolaan lubuk larangan.

Kemampuan masyarakat menanam dan mengembangkan modal sosial sesungguhnya bukan suatu hal yang baru sama sekali, namun selama berpuluh-puluh tahun di bawah pakem pembangunan Orde Baru yang bersifat sentralistik, hegemonik dan otoritarian, potensi-potensi modal sosial yang tumbuh dari bawah (grass roots) sering diabaikan, bahkan dimatikan; meskipun pada beberapa wilayah, mereka mampu bersiasat dari kondisi tidak sehat tersebut, terlihat dari kukuhnya pengelolaan sistem lubuk larangan yang relatif bebas dari campur tangan penguasa.

Keberhasilan pengelolaan sistem lubuk larangan dapat dirasakan khususnya ketika setiap tahun pemerintah menyalurkan dana Pembangunan Desa (Bangdes) ke desadesa melalui jalur formal, hasilnya sebagian hanyalah korupsi. Akan tetapi pengelolaan lubuk larangan yang dibangun dengan mengandalkan modal sosial (bukan modal material/finansial), ternyata mampu menghasilkan banyak hal di desa. Misalnya di Jambi, dimanfatkan untuk pembangunan gedung madrasah (seperti di Desa Hutarimbaru dan desa Singengu, Kecamatan Kotanopan), masjid (di banyak desa di Kecamatan Muara Sipongi, Kotanopan dan Batang Natal), menggaji guru SD Negeri (di Batang Natal), menyantuni anak yatim dan fakir miskin (di banyak desa Kecamatan Batang Natal), membangun jalan titi/rambin desa (di desa Koto Baringin, Kecamatan Muara Sipongi, desa Husor Tolang, Kotanopan ), dan banyak lagi contoh lainnya.
Dari keberagaman sistem-sistem lokal ini bisa ditarik prinsip-prinsip kearifan tradisional yang dihormati dan dipraktekkan oleh komunitas-komunitas masyarakat adat dalam kaitannya dengan upaya pengelolaan sumberdaya ikan di perairan umum, sebagai berikut.

(1) Ketergantungan manusia terhadap alam yang mensyaratkan keselarasan hubungan di mana manusia merupakan bagian dari alam itu sendiri yang harus dijaga keseimbangannya.

(2). Penguasaan atas wilayah adat tertentu bersifat eksklusif sebagai hak penguasaan dan/atau kepemilikan bersama komunitas (communal property resources) atau kolektif yang dikenal sebagai wilayah adat seperti petuanan di Maluku, dan ulayat dan tanah marga di sebagian besar Sumatera, sehingga mengikat semua warga untuk menjaga dan mengelolanya untuk keadilan dan kesejahteraan bersama serta mengamankannya dari eksploitasi pihak luar.

(3). Sistem pengetahuan dan struktur pengaturan (pemerintahan) adat memberikan kemampuan untuk memecahkan masalah-masalah yang mereka hadapi dalam pemanfaatan sumberdaya alam.

(4). Sistem alokasi dan penegakan hukum adat untuk mengamankan sumberdaya milik bersama dari penggunaan berlebihan, baik oleh masyarakat sendiri maupun oleh orang luar komunitas.

(5). Mekanisme pemerataan distribusi hasil panen sumberdaya alam milik bersama yang bisa meredam kecemburuan sosial di tengah-tengah masyarakat.

\section{Simpulan}

Penerapan model pengelolaan berbasis masyarakat terbukti dapat memberikan hasil yang cukup efektif dan efisien khususnya efisiensi pengelolaan, mereduksi konflik antar nelayan, dan keberlanjutan sumber daya laut dan pesisir. Dapat disimpulkan 
bahwa, indikator sistem sosial-budaya yang paling menentukan dalam keberhasilan pengelolaan berbasis masyarakat tersebut adalah tingkat partisipasi, kemampuan komunitas, dan konsistensi masyarakat.

\section{Daftar Pustaka}

Adrianto, L. 2011. Konstruksi Lokal Pengelolaan Sumberdaya Perikanan di Indonesia. Bogor: IPB Press.

Keraf, S. A. 2002. Etika Lingkungan. Jakarta: Penerbit Buku Kompas.

Ranger, Terence and Eric Hobsbawm. 1983. The Invention of Tradition. Sydney: Cambridge University Press.

Suhartini. 2009. "Kajian Kearifan Lokal Masyarakat dalam Pengelolaan Sumberdaya Alam dan Lingkungan," Seminar Nasional Penelitian, Pendidikan dan Penerapan MIPA. Yogyakarta: FMIPA Universitas Negeri Yogyakarta.

Wahono, Francis. 2005. Pangan, Kearifan Lokal dan Keanekaragaman Hayati. Yogyakarta: Penerbit Cindelaras Pustaka Rakyat Cerdas.

Wyadnyana, I Made. 2005. Eksistensi Tindak Pidana Adat dan Sanksi Adat dalam Kitab Undang Undang Hukum Pidana (Baru). Bunga Rampai Pembangunan Hukum Indonesia. Bandung: Eresco. 